Т. М. Мішеніна

\title{
ОСОБЛИВОСТІ ФУНКЦІОНУВАННЯ ФІТОНІМІВ БАРВІНОК, МАК І МАЛЬВА В УКРАЇНСЬКІЙ ЛІТЕРАТУРІ З ПОЗИЦІї ЛІНГВОМЕНТАЛЬНОСТІ
}

Мішеніна Т. М. Особливості функціонування фітонімів барвінок, мак $і$ мальва в українській літературі з позиції лінгвоментальності.

У статті розкрито особливості функціонування фітонімів барвінок, мак $і$ мальва в українській літературі з позиції лінгвоментальності, визначено шляхи розширення значень фітонімів-символів. Доведено ілюстративно, що в українській літературі фітоніми у своїй значеннєвій структурі поєднують традиційне й новаторське їх осмислення.

Ключові слова: фітонім, символ, лінгвоментальність.

Мишенина Т. М. Особенности функционирования фитонимов барвинок, мак и мальва в украинской литературе с позиции лингвоментальности.

В статье раскрыты особенности функционирования фитонимов барвинок, мак и мальва в украинской литературе с позиции лингвоментальности, определені пути расширения значений фитонимов-символов. Доказано иллюстативно, что в украинской литературе фитоними в своей смысловой структуре объединяют традиционное и новаторское их осмыление.

Ключевые слова: фитоним, символ, лингвоментальность.

Mishenina T. M. Peculiarities of the fitonim's periwinkle, poppy, mallow and in Ukrainian literature from the perspective of lingua, mental.

In this the peculiarities of the fitonim's periwinkle, poppy, mallow and in Ukrainian literature from the perspective of lingua, mental, ways to enhance values of the fitonim's characters. Proved that Ukrainian literature the fitonim's its semantic structure combine traditional and innovative them.

Key word: fitonim's, symbol, lingua, mental.

Наївна картина світу українського народу репрезентує квіти як рослини, що використовуються як прикраса будівель, садів, призначаються для дарування на свята. У науковій ботанічній картині світу квітковими 
називають усі рослини, що квітнуть хоч один раз протягом періоду функціонування. Ми схиляємося до думки, що лінгвістичний аналіз фітонімів у художньому мовленні доречно здійснювати, спираючись на уявлення наївної картини світу, оскільки мовна картина світу утворилася на основі наївної; позиція наукової класифікація не дозволяє здійснити грунтовне спостереження над функціональними особливостями фітонімів усі досліджувані рослини потраплять до одного розряду.

У XX ст. більш істотним став поділ квітів на польові (наприклад, ромашка, пролісок, мак, конвалія, волошка (васильок) тощо) та домашні (троянда, мальва, айстра тощо), хоч цей поділ також є відносним, оскільки конвалії, ромашки іноді вирощують у садках. Квітами також називають кімнатні декоративні рослини, навіть і ті, що не цвітуть. Представники трьох зазначених груп відрізняються роллю, призначенням, сферою використання, часом появи в символічній картині світу (наприклад, давніми квітами В. Німчук уважає рожу, мак, лілію [4, с. 233-292]).

Нашу увагу привернули фітоніми барвінок, мальва $i$ мак 3 позиції символіки, зокрема, поєднання в них традиційного й модерного їх осмислення.

Мета публікації - виявити особливості функціонування фітонімів барвінок, мальва $i$ мак в українській літературі 3 позиції лінгвоментальності.

3-поміж польових рослин найбільше функціональне й семантичне навантаження в українській культурі несе барвінок «Трав'яниста рослина 3 вічнозеленим листям і голубуватими квітами» [5, Т. I, с. 92]. Лексема барвінок запозичена 3 німецької мови Bärwinkel й означає «ведмежий куток», iii помилково асоціюють 3 лексемою української мови барва. «Поштовхом до народного етимологізування зазвичай стають мотиваційні психосемантичні зв’язки за формою (іноді й за змістом) між словами...» [6, с. 7-8].

Барвінок в українській літературі $є$ носієм етнокультурних нашарувань і має численні образні та символічні значення. Концепт барвінок поступово став утіленням народної символіки - вічного життя, безсмертя, людської душі, дівочої краси, цнотливості й чистоти, щасливого кохання й шлюбу, коханого чоловіка. Не випадково рослина здавна $\epsilon$ невід'ємною частиною символіки різних народних ритуалів i обрядів, зокрема весільного, а слово тим самим набуває вторинного, сакрального значення, бо разом 3 реалією виступає одним 3 аксіональних елементів відповідних обрядодій як етнокультурних контекстів [3, с. 52].

Прикладом символічного навантаження фітоніма барвінка - весни, незайманості та цнотливості - $є$ такі поетичні рядки: Найраніш процвітає Жовтенький горицвіт Та зелений дрібчастий барвінок [20, с. 32]; Нехай, доню, твоя руса коса В барвінку леліє» [20, с. 225]; Брала дівка воду $з$ броду, Коромисло гнеться; Стоӥть козак у воротях, Барвінком стелеться. Хоч стелися не стелися - Я не буду рвати; Хоч сватайся не сватайся - Не дасть мене мати [20, с. 230]. 
Символ парубка, туги та нещасного кохання спостерігаємо в таких текстових фрагментах: Ой де ідеш, квітчастий барвінку, Хто ж тобі постелить в дорозі постілку? [20, с. 114]; Ой ти, козаче, да хрещуатий барвіночку, Не люби дівчину да раненько в неділю [20, с. 356]; Ходила я по садочку, По зеленім барвіночку; Ой ходила та й блудила - Не є того, щзо-м любила» [20, с. 477]. Отже, фітонім барвінок традиційно є символом весни, цнотливості, образом парубка, може символізувати тугу та нещасне кохання.

В українських фольклорних текстах барвінок-хлопець набуває подальшого розвитку: "Дівчинонько, повна рожо, Чи сватати гожа?» «Козаченьку-барвіночку, Хоч у неділечку» [18, с. 59]. У народі вираз «рвати барвінок» означав «іти на побачення» [10, с. 152]: Пусти ж мене, мати, барвіночку рвати [18, с. 176]. Ліризм, сентиментальність, кордоцентричність українського етносу порівняно 3 іншими виявляється у функціонуванні дериватів 3 меліоративними суфіксами - барвіночок, барвінчик, барвінонько, барвінчичок, частотність використання яких у фольклорі перевищує використання нейтральної лексеми майже на 20\% (у мовній картині світу українського народу в XX ст. зменшено-пестливі форми становлять лише 6\%).

Барвінок переважно сполучається 3 дієсловом стелитися, що пояснюється особливістю росту: барвінок ніби вкриває землю, застеляє. Зелененький барвіночку, стелися низенько. А ти, милий чорнобривий, присувайсь близенько [18, с. 96].

Найпоширенішими означеннями фітоніма барвінок $€$ хрещзатий, зелений, кратчастий, що давно стали фольклорними епітетами, широковживаними в народному дискурсивному мовленні [3, с. 52]. Котрая зелень найкраще прочвіта: "Чи кратчастий барвіночок, чи запашний василечок, Чи повна рожа?» «Зелений барвіночок сади устилає» [18, с. 22-23].

Структура концепту барвінок української мовної картини світу $\mathrm{XX}$ ст. значно складніша, зникає поступово його використання в обрядах у технократичному суспільстві, але з'являються нові авторські інтерпретації. Перша складова концепту - пряме значення, яке, за спостереженнями, без символічних нашарувань майже не використовується: Барвінок стелеться в траві; В зеленій свіжій мураві Рясніють квітоньки [11, с. 11]. Результатом наявності широкого діапазону символів української культури стало те, що у XX ст. барвінок почав сприйматися як українська рослина взагалі, утративши відтінки між своїми символічними значеннями. Топче німець достигле колосся, Топче цввіт барвінковий в саду [17, с.5]; І землянки, щзо в серичі матусі-землі, I могили, щзо в серичі ї̈ барвінковім [17, с. 119] - барвінковий цвіт уособлює український народ, а барвінкове серце - м’яке, ліричне, сентиментальне українське серце.

Окрім лексичної сполучуваності 3 дієсловом стелитися та прикметниками хрещзатий, зелениц̆, барвінок може мати означення блакитний, голубий, синій [7, с. 24], що мотивується кольором квіток 
рослини: летюче буйство синє, як барвінок [11, с. 48]. У поетичному мовленні блакитний барвінок викликає асоціативні зв'язки 3 концептом небо: Та очима - в блакить, у небесні барвінки [11, с. 16]. У мовній картині світу ХХ ст. фітонім барвінок деякою мірою втрачає традиції використання в родинній обрядовості (символ краси, сили, постійності та вічності, молодості, кохання, шлюбу й щастя), значно розширюючи своє символічне навантаження [6, с. 63].

Глибокого символічного навантаження в українській літературі набуває фітонім мак. Тлумачний словник фіксує два значення лексеми мак: 1. Трав'яниста рослина 3 довгим стеблом і великими квітками (переважно червоного кольору), що дає кулястий плід, наповнений дрібним насінням; вирощується як лікарська та олійна культура, а також як декоративна рослина // Квітка цієї рослини. 2. Насіння цієї рослини [5, Т. II, с. 552]. Оскільки і квітка, і насіння маку були актуальними в побуті українського народу, вони утворили окремо один від одного широкі асоціативні групи, що зумовило виникнення багатоманітної системи образів і символів.

Згідно 3 нашими спостереженнями традиційно фітонім мак символізує красу дівчини: Ой, а бідна вдова Все плаче-ридає, А дівчина як мак процвітає! [20, с. 32]; Ой-бо у мене дочка Явдошка як маковий иввіт, Коли хоч, бери дівку Явдошку на иүілий свій вік [20, с. 41]; Ой зацвіла маківочка Білесеньким цввітом - Іде козак од дівчини Білесеньким світом [20, с. 86]; А в бідної дівчиноньки Намиста немає, Попід гору несе воду Як мак проиявimaє [20, с. 237].

Функціональним $\epsilon$ символ швидкоплинного життя. Символічне навантаження реалізується на основі паралелізму розвитку рослини і віку людини: Ой не жаль мені, щзо мак зійшов. Ой як жаль мені, щзо вік пройшов. Пройшов мій вік, як маків цзвіт, Що вночі цзвіте, вдень опаде, Так мій вік марно пройде [20, с. 414].

У веснянках втілено давні світоглядні уявлення про весняну життєдайну природу, шанобливе ставлення до неї. Спостерігаємо уособлення образу маку: Мак, мак, моя маківочка, Золотая головочка! Станьте ви, дівки, В червоний мак. Да не пускайте пана з хоровода, Нехай дає мак... [20, с. 71].

Сюжетна лінія веснянок також містить опоетизовані дії садіння, зростання i збирання маку, що надає неповторного романтизму й естетичної краси споглядання розвитку природи: Воробчику, шпачку, шпачку, Ци був ти в нашім садку? Ци видів ти, як мак воруть? - Вой вотак воруть мак; Ци видів ти, як мак сіють?... Ци видів ти, як мак сходить?... Ци видів ти, як мак росте?... Ци видів ти, як мак цвіте?... Ци видів ти, як мак жннть? Ци видів ти, як мак їдять? [20, с. 74].

Квітка маку може слугувати для означення національної приналежності пейзажу, а також для ще більшої його локалізації: маки ростуть у природних умовах у зоні степу: Маки в житі ридали 
пелюстками зірваних сліз [10, с. 75]. Мак іноді вирощують як декоративну рослину, тоді він з'являється в топосі городу: Пшениия в полі, маки на городi $[16$, с. 518].

Маки символізують також пору року - літо: Цілувало літо до нестями, Загубився з ліку бій сердець. Назбирало маків між полями I пішло зі мною під вінещь [11, с. 23]. Зів’ялі квіти можуть вказувати на прихід осені: Вечір сухий кумач зів ялого маку з копиці підняв [11, с. 183].

Мак сприймається свідомістю українця як типова українська «рідна» рослина: Хоч би в тім раї було все, як у Раї, - так само... Щоб посиденьки, цчигарка, щзоб чорнобривці $i$ мак [14, с. 40]. Незважаючи на те, що нині вирощують декоративні маки білого, жовтого, рожевого та інших кольорів, все ж у свідомості стереотипним кольором виступає червоний, саме він належить до концептуального ядра. На основі кольору з'явилися порівняння $з$ маком: Твоя хустина ніби мак, але бліда щзока [11, с. 65]. Утворений від іменника мак прикметник маковий частіше вживається зі значенням «червоний» і рідко - «той, що належить маку, подібний до маку», первісна семантика відійшла на периферію. Пливе гречин у маковій сорочиз $[16$, с. 454$]$.

Мак, як багато інших рослин з позитивною символікою в українській ментальності, може асоціюватися з чимось хорошим, приємним, але чітко не визначеним: Тичуть пальцеем в лице I показують звихнуті знаки. В них душа не пече, Не цвітуть $і$ червонії маки [11, с. 16]. Це значення може набувати додаткової семи «жура» часто в контексті втрати: Маковія задмухує маки і роздмухує в серці журу [14, с. 38]; червоні маки болючий спомин тихе ридання [15, с.51]. Мак, що виступає символом тихих, спокійних спогадів, не уособлює болю і ридань. В останньому прикладі спостерігаємо нашарування: мак - українська рослина, не бачити маків означає не жити на Україні, тоді спогади про маки як символ втраченої Вітчизни будуть болючими.

Одним 3 найбільш уживаних символічних значень концепту мак виступає «сон, спокій, забуття». Це значення превалювало в грецькій та римській міфологіях [7, с. 138; 10, с. 154]. На Україні відвар з макових голівок використовували як снодійний, заспокійливий засіб. У сучасному поетичному мовленні доволі рідко спостерігаємо це символічне значення, що пов'язано, можливо, з появою інших методів лікування й забуванням народом давніх традицій. Ходив Бог по горі сіяв маки у дворі Божа Мати маки жала... хай би рожденна моленна раба Божа Тетяна забула все щзо кохала [9, с. 57], - у наведеному прикладі мак є символом забуття, спокою.

Поширеним символічним значенням концепту мак також уважається «зоря», «безмежність зоряного світу» [3; 8]. Символічне перенесення відбулося на основі численності макових зернят, що нагадувало численність зірок. Але в сучасних поетичних творах символічне значення «зоря» 
перенесене й на макову квітку за ознаками подібності: Напевне, так і треба судилося бо так: упали зорі з неба і надломили мак [19, с. 127].

До семантичного ядра концепту мак належить і символічне значення «безневинно пролита кров, кров загиблих воїнів, козаків» [7, с. 138-139; 10, с. 154], оскільки вважалося, що на тому місці, де пролилася кров, виростають червоні маки. Ординці воїна скришили, На землю впало тіло біле I, наче зерно, проросло, А влітку маком зацвіло [7, с. 139].

Традиційною складовою концепту мак є порівняння 3 ним гарної дівчини, у фольклорі мак був символом красивої дівчини, а з маківкою могли порівнювати матір [7, с. 138-139]. А в бідної дівчиноньки намиста немає, Попід гору несе воду - як мак проиявітає [18, с. 47]. У свідомості сучасних українців це символічне значення відходить на периферію, спостерігається поодиноко: хто ти після того лайдаку козак три дівки три любки і кожна як мак [18, с. 42].

У сучасному поетичному мовленні мак використовується для зображення аномалій життя, підкреслення контрасту між нормою, традицією й відхиленням. Сарана чаду несеться з маньчжурських степів... я перестав дивуватися задовго до того як побачив щзо маки кров землі жовті у спустошеному трунті [15, с. 81], - на чужині й маки не такі, як на Батьківщині. Зібрано з клумби... дрібні маківки [13, с. 76], - мак може вирости великий тільки на волі, а в місті, на клумбі, у штучних умовах маківки ростуть дрібні.

Як зазначалося вище, макове насіння, що теж називають маком, утворило свою групу асоціацій. Оскільки його часто використовували для приготування страв, то це й стало основним значенням. Ходи хутчіше де ти с я знову вкрав із маком булку [17, с. 76].

Макове насіння є символом великої кількості, оскільки в маківці безліч зернят; одна зернина символізує щось надзвичайно маленьке, перенесення відбувається на основі зовнішньої подібності: $i$ дякуєм Тобі, щзо нас удвох залишив на день, на ніч, на хліб, на сіль, на мить, як мак, як вік сніжини, щзо атакує огнище поганське [14, с. 24]. Макова пелюстка на основі зовнішньої подібності набуває символу легкості, ніжності: Куди його, як макову пелюстку, тисячолітнім вітром занесло? [16, с. 464].

Отже, структура концепту мак досить складна, вона налічує кілька семантичних центрів: рослина, квітка, насіння, плід (коробочка) - кожен 3 них утворює свій асоціативний діапазон, має лексичне, кілька символічних та образних значень, які на периферії перетинаються й взаємно доповнюються, а це призводить до появи складних полісемантичних символів.

Глибокого символічного навантаження в українській національній свідомості набуває фітонім мальва. В українській мові фітонім представлено двома лексемами - мальва й рожа, що мають однакову семантику й не відрізняються за функціональними стилями; зауважимо, що рожею можуть називати троянду. Лексема мальва запозичена з латинської 
мови, латинське malva походить від гебрайського й споріднене зі словами «сіль, їдкий, колючий» [5, Т. III, с. 374]. Концепт містить поняття «Багаторічна декоративна рослина 3 високим стеблом i великими яскравими квітами, зібраними по кілька в пазухах листків, іноді в китицеподібні суцвіття» [5, Т. II, с. 564].

За подібністю квіток назву рожа в багатьох українських говірках перенесено на мальву, і з цим значенням вона входить до нормативної ботанічної номенклатури [4]. Концепт мальва характеризується тим, що має власне українську символіку; мальва означає символ найдорожчого любові до рідної землі, свого народу [7, с. 30]. Цей символ і локалізація біля хат у селі й посідає провідне місце в символічному змістові фітоніма: Вечір був. І извіли під вікнами мальви [16, с. 32].

Спільна сема «зовнішня краса» зумовлює активне функціонування асоціативного ряду мальва - дівчина, що зумовлено фольклорною традицією образного паралелізму: Ой дівчино, дівчинонько, Яка ж бо ти гожа: Як у саду під віконцем Та зац̧віла рожа! [18, с. 40]. Оскільки у свідомості представників української ментальності витворилася типова картина рідної домівки - хата в обрамленні мальв, то квітка поступово сприймається як рідна, українська, наймиліша: Ну щзо мені магнолії, агави? Я поцілую мальву у щзоку [16, с. 112]. Якщо в селі ростуть мальви, воно автохтонно українське: В сих краях при огорожі жодні рожі не ростуть $[15$, с. 30] - не Україна.

Незвичну форму фітоніма мальва покладено в основу метафор (подібність стовбура до колони, свічки, квітки - до мегафона: згорів у танизі хоровод беріз, і мальви, як свічки, повідгоряли [16, с. 145]; Півні кричать у мегафони мальв [16, с. 161]. Структура символічного значення мальва містить елементи, притаманні всім квітам (вони ростуть, цвітуть, символізують красу навколишнього світу), додаткових відтінків набуває ядерний символ, нівелюючи актуальність прямого значення.

Макросимвол квіти з часом змінюється: відходять на периферію свідомості сучасного українця традиційно осмислені фітоніми-символи. Зокрема, переосмислюються значеннєві компоненти символів барвінок, мальва, мак, натомість констатуємо нові денотати.

Структура аналізованих фітонімів включає денотативне значення, інформацію про якісні ознаки, типові локуси, функції квітів та можливості їх використання, ключовий символ «краса», що утворився 3 іманентної ознаки квітів, периферійні символи $є$ доповненнями, узагальненнями ядерного. Наявні численні порівняння, метафори, словотвірне гніздо лексеми містить багато дериватів. Незважаючи на те, що фітоніми і не мали в житті носіїв української культури суто господарського значення, вони увійшли до картини світу як об’єкт милування, вияву такої типової риси українського характеру, як сакральний символ непроминущості народу, естетизм, ліризм. 
Ядра фітонімів містять поняття, зовнішні та якісні характеристики, типові можливості використання, загальноприйняті локуси, основні символи. 3 часом відходять на периферію і втрачаються сакральні елементи, давні вірування. Значення фітонімів-символів постійно перебувають у процесі творення, тож провести чітку межу між ядерною та периферійною зонами неможливо. Окрім змін у структурі самих фітонімів, відбувається розширення за рахунок зв'язків з іншими фітонімами.

\section{Література}

1. Бибик С. П. Словник епітетів української мови / С. П. Бибик, С. Я. Срмоленко. - К. : Довіра, 1998. - 432 с.

2. Веселовский А. Н. Историческая поетика / А. Н. Веселовский. - М. : Высшая школа, 1989. - 408 с.

3. Жайворонок В. В. Проблема концептуальної картини світу та мовного іiі відображення / В. В. Жайворонок // Культура народов Причерноморья. - Симферополь : СГУ, Крымский научный центр НАН Украины. - 2002. - № 32. - С. 51-53.

4. Німчук В. В. Давньоруська спадщина в лексиці української мови / В. В. Німчук. - К. : Наукова думка, 1992. - 416 с.

5. Новий тлумачний словник української мови : у 4-х т. - К. : Аконіт, 1999. - Т. 1-4.

6. Пітель В. М. Типологія епідигматичних відношень полісемічних флороназв та їх похідних у лексиці сучасної української мови : автореф. дис. на здобуття наукового ступеня канд. філол. наук / В. М. Пітель ; Прикарпатський нац. ун-т імені В. Стефаника. - Івано-Франківськ, 2005. - 19 с.

7. Словник символів культури України / за ред. В. П. Коцура та ін. - К. : Міленіум, 2002. - 260 с.

8. Усик Л. М. Оцінні значення в ознаках та базисах фітонімів / Л. М. Усик // Мовні і концептуальні картини світу : зб. наук. праць. - К. : КНУ ім. Т.Шевченка, 2004. - №10. - С. 617-625.

9. Чудак М. Д. Українські обрядові символи, пов'язані з народженням дитини, в українців Придністров'я / М. Д. Чудак // Мова і стиль українського фольклору. - К. : ІЗМН, 1996. - С. 57-63.

10. Шейнина Е. Я. Энциклопедия символов. - М. : ООО «Изд-во АСТ», Харьков : ООО «Торсинг», 2002. -592 c.

\section{Список використаних джерел}

11. Гуцало Є. П. Напередодні нинішнього дня : Лірика / Є. П. Гуцало. - К. : Радянський письменник, 1989. $-272 \mathrm{c}$.

12. Далекі зірниці. Українська література першої половини XX ст. - К. : Грамота, 2002. - 480 с.

13. Драч І. Ф. Сонце і слово. Поезії / І. Ф. Драч. - К. : Дніпро, 1978. - 368 с.

14. Жиленко І. В. Пори року: Вірші та поеми / І. В. Жиленко. - К. : Український письменник, 1999. - 136 с.

15. Калинець І. Ці квіти нестерпні. Малий поетичний зільник / Ігор Калинець. - К. : Факт, 2000. - 94 с.

16. Костенко Л. В. Вибране / Л. В. Костенко. - К. : Дніпро, 1989. - 560 с.

17. Крізь пам'ять. Збірка поезій. - Одеса : Астропринт, 2005. - 196 с.

18. Пісні кохання. Народна творчість / гол. ред. Д.В. Павличко. - К. : Дніпро, 1986. - 368 с.

19. Стус В.С. Палімпсест : Вибране / В.С. Стус. - К. : Факт, 2003. - 432 с.

20. Українські народні пісні - К. : Дніпро, 1964. - 588 с.

Стаття надійшла до редакції 28.11.2011 p. 